\title{
Barış Çalışmalarında Sosyal Temsiller Kuramı: Gruplararası Farklılıklar ve Bağlamsal Etkiler
}

\author{
Kübra Özkan Demir*
}

\section{Öz}

Sosyal inşacı yaklaşımlardan biri olan sosyal temsiller kuramı barış, savaş ve çatışmanın doğası, süreci ve sonuçlarının anlaşılmasına katkı sunmaktadır. Bu çalışmada sosyal temsiller kuramı çerçevesinde yürütülen barış, savaş ve çatışma ile ilişkili çalışmalar bağlamsal etkiler göz önünde bulundurarak incelenmiştir. Hem nitel hem de nicel araştırmaların bulgularının incelendiği bu çalışmada barış ve savaş temsillerinde cinsiyete ve yaşa göre ayrışmalar olduğu; aynı zamanda tarihsel, politik ve kültürel bağlamlara özgü olarak barış ve savaş temsillerinin içeriklerinin toplumsal gruplara ve uluslara göre farklılaştığı ve dönemsel olaylardan etkilenerek değiştiği sonucuna ulaşılmıştır. Öte yandan incelenen boylamsal çalışmalarda sosyal temsillerin özünün büyük ölçüde korunduğu, çevresel elementlerde güncel toplumsal tartışmalara bağlı olarak değişimler olduğu dikkati çekmektedir. Bu yönüyle barış ve savaş temsilleri tarihsel süreç içerisinde nesiller boyu aktarılan özelliklere sahip olsa da, zamanın koşullarından etkilenerek dinamik bir yapı da sergilemektedir.

Anahtar Kelimeler: Sosyal Temsiller Kuramı, Barış, Savaş, Çatışma, Gruplararası Farklılıklar, Bağlamsal Etkiler.

\section{Social Representations Theory in Peace Studies: Intergroup Differences and Contextual Effects}

\section{Abstract}

Social representation theory is a social constructivist approach used as a tool to understand the nature, process, and consequences of peace, war, and conflict. Here, we examined studies related to peace, war, and conflict conducted within the framework of the theory of social representations by considering contextual effects. The findings of both qualitative and quantitative studies suggest that there are differences in the representations of peace and war based on gender and age. In addition, the contents of the representations of peace and war specific to historical, political, and cultural contexts differ according to social groups and nations and change as a result of the influences of periodic events. Nevertheless, it is also needed to note that the core of social representations has shown to be preserved to a great extent in the longitudinal studies examined, and there are changes in periphery elements depending on current social debates. In this respect, although the representations of peace and war have features that have been passed down through generations in the historical process, they also exhibit a dynamic structure influenced by the conditions of the time.

Keywords: Social Representations Theory, Peace, War, Conflict, Intergroup Differences, Contextual Effects.

*Uzm. Psk., Doktora Öğrencisi | Uludağ Üniversitesi Psikoloji Bölümü

kubraozkan88@gmail.com | ORCID: 0000-0001-7230-8467 | DOI: 10.36484/liberal.935668 Liberal Düşünce Dergisi, Yıl: 26, Sayı:103, Yaz 2021, ss. 37-60.

Gönderim Tarihi: 10 Mayıs 2021 | Kabul Tarihi: 30 Temmuz 2021 


\section{Giriş}

Sosyal temsiller, topluluklar tarafından ortak olarak paylaşılan idea, düşünce, imgelem, inanç ve bilgi olarak tanımlanmaktadır (Moscovici, 1981). Sosyal gerçekliğin birçok yönünü adlandırmaya yarayan ve çevre ile olan ilişkilerin anlaşılmasını kolaylaştıran temsiller iki ya da daha fazla kişi arasındaki etkileşime dayanmaktadır. Toplum tarafından üretilirler ve toplumsal iletişim aracılığıyla ortak bilincin parçalarını oluştururlar. Gündelik yaşam deneyimlerinin doğal akışı içinde ortaya çıkmaktadır. Bu nedenle sosyal temsilleri çalışmak toplumun dinamik anlatımlarını/söylemlerini çalışmak anlamına da gelmektedir (Philogene ve Deaux, 2001).

Sosyal temsiller kuramı, modern toplumlardaki psikososyal fenomenlerin incelenmesinde kullanılan kavramların ve ideaların bir tür çatısı durumundadır. Sosyal temsiller yaklaşımı bu sosyal-psikolojik fenomenlerin tarih, kültür, ekonomi gibi makro sistemler içerisinde gömülü olduğunu, özne ve nesnenin birbirinden ayrışık olmadığını varsayarak sosyal psikolojide yaygınlıkla kullanılan teorilerin ve yaklaşımların bireysellik üzerine kurulu yöntemsel kısıtlılıklarını aşmanın yolunu açmıştır (Moscovici, 2001). Sosyal temsiller yaklaşımında nesne bir bağlam içinde öznelerarası etkileşimler yoluyla anlam ve işlev kazanır. Abric (2001) önceden belirlenmiş nesnel bir gerçekliğin olmadığını, aksine gerçekliğin tarihsel, sosyal, ideolojik bağlam içinde mükerrer tezahürleri ve yorumlanması ile bengi-dönüşsel yani başı-sonu olmayan bir şekilde inşa edildiğini öne sürmektedir.

Moscovici (2008) sosyal temsil süreçlerinin konunun tehdit edici ya da tartışmalı olduğu durumlarda daha işlevsel ve erişilebilir hale geldiğini öne sürmektedir. "Barış" ve "savaş", özelikle insani krizlerin yaşandığı dönemlerde dost, düşman, saldırgan ve savunmacı gibi rol temsillerinin yeniden ele alınması sebebiyle farklı bir bağlam içinde sahnelenen sosyal temsillere dönüşmektedir. Bu açıdan savaş ve barış bağımsız değişkenler değil bağımlı değişkenler olarak ele alınmalıdır. Aktörlerin ve rollerin yeniden karıldığı bir bağlamda savaş ve barış eski bağlamlardan ve temsillerden tam bir kopuş gerçekleşmeden yeniden kurgulanan ve anlamlı hale gelen bir "olaylar" haline gelir. Bu açıdan savaş ve barış kavramları sosyal temsiller kuramı çerçevesinde ele alınmaya değer görülmektedir.

Barış kavramı, kişilerarası, gruplararası ve uluslararası iletişimde ve dünya üzerindeki savaşa ve çatışmalara karşı hareket eden kitleler tarafından sıklıkla kullanılan değer yüklü ve bağlamsal bir temsildir (Cortright, 2008). Barış farklı temsilleriyle örneğin kişinin kendisiyle barışık olması ve küresel barış gibi yeri geldiğinde bir fiil, bir karakter ve bir değer olabileceği gibi belli bir iktidar 
söylemi içinde güçlünün zayıfa müstahak gördüğü şiddetin ope-(ra)syonel adı bile olabilmektedir. Barış içinde huzurlu bir yaşam sürmek her ne kadar hem bireyler hem de toplumlar için elzem bir değere sahip olsa da, barıştan ne anlaşıldığı kültürel, tarihsel, politik ve ideolojik bağlamlara göre değişkenlik gösterebilmektedir. Sosyal temsiller yaklaşımı sözü edilen bağlamlar arasındaki ilişkilerden doğan anlamların incelenmesine de olanak sunmaktadır. $\mathrm{Bu}$ çalışmada savaş, barış ve çatışma üzerine yapılan çalışmalar Serge Moscovici'nin öne sürdüğü sosyal temsiller kuramı bağlamında incelenecektir.

\section{Kuramsal Çerçeve}

\section{Sosyal Temsillerin İşlevleri}

Sosyal temsiller yabancı olanı, rahatsız edeni ve anlaşılmaz olanı bilindik/ tanıdık hale getirmek için üretilirler (Hoijer, 2011). Gerçekliğin sosyal temsillerinin yeniden inşası iki aşamalı bir süreçtir: 1) Demir atma (anchoring) 2) Nesneleştirme (objectification). Demir atma, yeni bir şeyin (olayın) daha önceden -büyük olasılıkla çağrışım veya benzeştirme yoluyla- zihinsel sistem içerisinde var olan başka bir şeyin (olgusal bir anlamı olan şema veya kategorinin) halesi veya içericinde konumlandırılmasıdır. Böylece yeni, yabancı, garip fikirlerin, nesnelerin ya da olayların tanıdık bir bağlam ya da kategori içerisinde yeniden düzenlenmesi sağlanır. Nesneleştirme ise demir atma ile bu yeni objenin (şey artık bir nesneye dönüşmüştür) sembolik bir özgüllüğe kavuşturularak nesnelleştirilmesidir. Diğer bir deyişle, soyut bir kavram, idea ya da imajın (imge ya da gösterilenin) dilin göndergesel işlevi ile daha somut ve nesnel bir 'şey' içerisinde veya şey (görüngü) olarak tanımlanarak sosyal gerçeklik (gösterge) haline gelmesidir (Moscovici, 1984; Philogene ve Deaux, 2001). Farklı, aşina olunmayan şeyler aynı zamanda bireyleri psikolojik anlamda tehdit eden şeylerdir. Demir atma ve nesneleştirme aracılığıyla bu psikolojik gerginlikten kurtulma yolu açılmış olur. Sosyal temsilleri bir tür sembolik baş etme yöntemi olarak ele almak mümkündür (Jost ve Ignatow, 2001).

Moscovici (1988) temsillerin grup üyeleri arasındaki ilişkilere bağlı olarak 'sosyal' görünüme dönüşmesinde kullanılan üç farklı türde temsilin olduğunu ileri sürmektedir. Temsiller parti, şehir ya da ulus gibi bir üst yapı içindeki üyeler arasında paylaşılabilir. Bu tür temsiller hegemonik (baskın) temsiller olarak adlandırılmaktadır. Hegemonik temsiller tüm sembolik ya da duyuşsal pratiklerde örtük olarak bulunmaktadır. Bu temsiller tek tip, homojen ve kalıcıdır. İkinci gruptaki temsiller ise birbirlerine görece yakın temas içerisinde olan alt grupların etkileşimleri sürecinde ortaya çıkan temsillerdir. Her alt 
grup çerçevesinde kendine özgü temsiller üretir ve diğer gruplarla paylaşır. Grup düzeyinde temsiller olarak adlandırılan bu temsiller özerk, gruba özgü, eşgüdümlü özelliklere sahiptirler. Son grupta ise toplumsal çatışmalar, anlaşmazlıklar ve muhalefet sırasında ortaya çıkan, toplumun bütününde ortak olarak görülmeyen münakaşalı (polemical) temsiller bulunmaktadır. Sosyal ve politik hedeflerin/mücadelelerin gerçekleştirilmesinde bu tür temsiller bir tür sistemi meşrulaştırma işlevi görmektedir (Jost ve Ignatow, 2001). Bu bağlamda Jost ve Ignatow (2001) ortak üretilen temsiller aracılığıyla grup aktivitelerinin koordine edildiği ve bireyler arasındaki iş birliğinin kolaylaştığını öne sürmektedirler. Toplumsal olarak paylaşılan temsiller sayesinde ortak bir hedef için kitlesel olarak hareket etmek mümkün olmaktadır. Grup ya da toplumla beraber hareket etmek için topluluklar kültürlerine uygun kurumlar yaratırlar, ortak normlar geliştirirler ve ortak kuralları takip ederek inanç sistemlerini oluştururlar (Philogene ve Deaux, 2001).

\section{Sosyal Temsillerin Yapısı: Merkezi ve Çevresel Bileşenler}

Sosyal temsillerin yapısal özelliklerinin inceleyen Abric (2001), sosyal temsilleri birincil ve ikincil öneme sahip bileşenlerden oluştuğunu öne sürmüştür. Sosyal temsiller birincil öneme sahip merkezi (central) bileşen etrafında, temsile anlamını veren bir ya da daha fazla çevresel (periphery) bileşenden oluşmaktadır. Merkezi öz (central core) temsile genel anlamını ve değerini veren yapıdır. Sürekli değişen çevre içerisinde yeni bilgilere nasıl tepki vereceğini belirleyerek yeni çevresel temsillerin üretilmesini ve/ya merkezi özün kendi içinde farklı bir öze dönüştürülmesini sağlar. Ancak tarihsel ve ideolojik kökene sahip olduğu ve değişime dirençli olduğu için de nispeten durağan bir yapıya sahiptir. Merkezi öz üretici rolünün yanı sıra, organize eden işlevi de bulunmaktadır; temsil bileşenlerinin birbiriyle olan ilişkilerini düzenlemekte, birleştirmekte ve sabitlemektedir. Bu birleştirici ve üretici gücü ile merkezi öz değişime en çok direnç gösteren bileşendir. Merkezi özün değişimi, temsilin ancak bütünüyle yeni bir içeriğe dönüşmesiyle mümkün olmaktadır. Diğer bir ifadeyle etkili bir dönüşüm merkezi özün sorgulanmasıyla mümkün olmaktadır.

Çevresel bileşen ise merkezi öz etrafında organize olmaktadır. Merkezi öze kıyasla daha ulaşılabilir parçadır, aynı zamanda daha esnek ve somut yapıdadır. Somutlaştırma, adaptasyon ve savunma olmak üzere üç temel işlevi bulunmaktadır. Bağlama duyarlı bir yapıda olan çevresel bileşenler, demir atma yoluyla gerçekliğe kavuşmaktadır. Çevresel bileşenler temsilin kendini genişlettiği ve kendini gösterdiği somut alanda kapsanır. Somutlaştırma işlevi aracılığıyla, temsilin anında kavranacak ve iletişim esnasında açıkça 
iletilebilecek şekilde somut kavramlarla anlaşılmasına izin vermektedir. Çevresel bileşen, merkezi özden daha esnek bir yapıya sahiptir. Değişen çevreye ve yeni edinilen bilgilere uyum sağlamada önemli rolü bulunmaktadır. Son olarak ise çevresel bileşenin savunma işlevi bulunmaktadır. Çünkü değişime dirençli bir yapı olan merkezi özün içeriğini temsile ters düşen bilgilere karşı koruma görevi üstlenmektedir. Her yeni, garip ve farklı bilgide temsil özünün terk edilmesi ve içeriğinin değişmesi mümkün olmadığı için, daha esnek bir yapıyı temsil eden çevresel bileşen karşıtlığı meşrulaştırarak temsilin devamlılığını sağlamaktadır.

\section{Barış Psikolojisi ve Temel Kavramlar}

Barış psikolojisi; şiddetin sergilenmesine yol açan zihinsel süreçler ve davranışlar üzerine çalışmaktadır. Şiddeti önlemeyi ve şiddetsizlik idealine ulaşmayı, herkes için adaletli, saygın ve onurlu yaşamın inşa edilmesini hedefleyen bir disiplindir (Macnair, 2015). Her ne kadar psikoloji disiplini şiddet, saldırganlık, önyargı, ayrımcılık gibi meselelerle uzun süredir ilgileniyor olsa da şiddetsizlik bağlamında barış, silahsızlanma ve çatışma çözümünü kapsayan barış psikolojisinin tanınması ve bu alanda yapılan çalışmaların artış1 1980ler ve 90lara denk gelmektedir. Bu dönemde Amerikan Psikoloji Derneği bünyesinde Barış Psikolojisi Birimi kurulmuştur. Ralph K. White, Herbert Kelman, Doris Miller, Ethel Tobach, Morton Deutsch gibi psikologlar barış psikolojisi alanında yaptıkları çalışmalarla tanınmaktadırlar (Wessels vd., 2010). Dünya üzerinde kitleleri etkileyen savaşlar ve çatışmaların, yasadışı ayrılıkçı oluşumların, bağımsızlık savaşlarının, sivil savaşların sıklıkla gündeme gelmesi ve uluslararası savaşların yerini etnik, dini, kültürel, politik iç-çatışmalara bırakması barış psikolojisinin 1990'lar ve sonrasında da önemini korumasını sağlamıştır (Blumberg, 2006; Christie vd., 2001). 1990'lar ile birlikte barış psikolojisi disiplinlerarası alana açılmış ve birey düzeyinde ele alınan bilişsel-motivasyonel faktörlerden ziyade makro düzey faktörlerin analizini içeren yaklaşımlar hâkim olmaya başlamıştır. Artık barış psikolojisinde coğrafi-tarihsel bağlama duyulan ilgi artmış, barış ve şiddetin türleri ve anlamları daha fazla ayrıştırılmış, şiddet ve barışın doğasına sistemik bir bakış açısı getirilmiştir (Liu ve Sibley, 2009).

Barış kavramına kapsamlı ve çok yönlü bakışın geliştirilmesinde Galtung'un (1969) pozitif barış ve negatif barış ayrımı önemli yer tutmaktadır. Negatif barış bireylere akut ve belirgin şekilde zarar verme anlamına gelen aleni şiddetin ortadan kaldırılması demektir. Pozitif barış ise yoksulluk, doğanın sistematik bir şekilde tahrip edilmesi, orantısız gelir dağılımı, 
tehlikeli çalışma koşulları, cinsiyetçilik, ırkçılık ve ayrımcılık gibi çeşitli kronik formları içeren yapısal şiddetin ortadan kaldırılması anlamına gelir. Kısacası, bir kültürde tam anlamıyla barıştan söz edebilmek için şiddet olasılığının azaltıldığı her türlü olumlu toplumsal koşulun yaratılması gerekir. Bu anlamıyla aleni şiddetin ortadan kaldırılması olarak 'negatif barış' ve yapısal şiddetin ortadan kaldırılması olarak "pozitif barış" kalıcı barış için veya barış inşa sürecinin iç içe geçmiş birbirini destekleyici iki boyutu olarak düşünülebilir. Çünkü aleni şiddet yapısal şiddete, yapısal şiddet de aleni şiddete yol açabilir.

Barış ortamının sağlanması ve sürdürülmesine ilişkin geliştirilen diğer kavramlar ise barış yapma (peacemaking) ve barışı kurma (peacebuilding) kavramlarıdır. Barış yapma, aleni şiddetin yoğunluğunu ve sıklığını azaltmayı hedeflemektedir. Çatışmanın önlenmesi için taraflar arasındaki diyalogun ve karşılıklı anlayış/güvenin sağlanması, tarafsız aktör/lerin arabuluculuk yapması ve sürecin sonunda her iki tarafın da şiddetin durdurulmasından fayda sağladığı ortamın oluşturulması önemlidir. Barış yapma, dönemsel ve bölgeseldir. Öte yandan barış kurma, toplumsal adaletin sağlanması ve uzun-döneme yayılmış yapısal eşitsizliklerin giderilmesini amaçlar. Sürdürülebilir barış için kültürel, politik ve ekonomik dönüşümlerin sağlanması ana hedeflerdir (Christie vd., 2001). Ancak barışı kurmak ve sürdürmek statik kavramlar değildir. Barış sürecinin nasıl ilerlediği gruplararası ilişkilerin tarihi, sosyo-politik iklim, ekonomik koşullar, dış-grupların barışın sağlanmasına ilişkin tutumları gibi arka plan özelliklerine; kurumlar, aile ve doğrudan temas aracılığıyla aktarılan değerler ve anlatılara; bireylerin sahip olduğu özelliklere (değerler, tutumlar, motivasyonlar vb.) bağlı olarak değişkenlik gösterebilmektedir (Bar-Tal,1997).

\section{İncelenen Çalışmaların Genel Özellikleri}

Bu çalışmada Serge Moscovici'nin sosyal temsiller kuramı çerçevesinde "barış", "savaş” ve "çatışma” ile ilişkili yapılan çalışmalar incelenmiştir. Sosyal temsillere ilişkin yapılan çalışmalarda doğası gereği yorumlayıcı yaklaşımlar benimsenmektedir. Sosyo-politik konulara ilişkin sosyal temsiller çalışılırken genelde iki özgün yöntem kullanılmaktadır (Elcheroth vd., 2011). Bunlardan ilki daha bilişsel ve yapısal yaklaşımı yansıtmakta olup, sosyal temsillerin bir sosyal objeye ilişkin bir grubun ya da toplumun bilişsel yapısını yansıttığı fikrinden hareket etmektedir. Bir yapıdan hareket eden her yaklaşım elbette indirgemecidir ancak diğer indirgemeci yaklaşımlardan farklı olarak bilişsel-yapısal yaklaşıma göre sosyal temsillerin yapısı bir grup içerisindeki bireylerin bilişlerinin birikmiş toplamı değil, grup üyelerinin birbiriyle 
etkileşimleri sonucunda oluşan yeni bir grup zihni ve zihniyeti (bilişi) olarak anlaşılmalıdır. Her ne kadar sosyal biliş psikanalizin bilinçaltı ile karıştırılmaması gereken bir bilme biçimi olsa da bu yöntemin kullanıldığı çalışmalarda genelde sosyal temsil yapısını analiz etmek için serbest çağrışım yöntemleri kullanılmaktadır (Abric, 2001). Daha nicel bir araştırma olan içerik analizleri ile topluluğun yaygın ve sık olarak kullandığı kodlar, kalıplar ve temalar istatistiksel olarak ortaya konur. İkinci metodolojik yaklaşımda ise herhangi bir indirgemecilikten kaçınarak sosyal temsilleri iletişimin ürünü olarak görmeyi tercih eder. İletişimsel veya söylemsel yaklaşım bir sosyal olgu ya da obje hakkında üretilen söylemlerin altında yatan anlam ve anlatıların incelenmesini kapsamaktadır. Nitel analiz yöntemlerinden söylem/ metin analizleri, odak (tartışma) grupları ve derinlemesine mülakat tercih edilir. Bu çalışmada da barış, savaş ve çatışmaya ilişkin temsillerin yapısını ve içeriğini inceleyen makalelerin yanı sıra; odak grup çalışması, yarı yapılandırılmış görüşmeler gibi iletişim sürecinin aktif olarak işlediği çalışmalar, sözlü ve yazılı belgelerin içeriğinin analiz edildiği makaleler derlenmiştir. İncelenen çalışmaların genel özellikleri Tablo l'de sunulmuştur.

\section{Nicel Bulgular}

\section{Barış ve Savaş Temsillerinin İçeriği}

Temsil yapısını ve içeriğini ortaya koymada kullanılan çağrışım testleri aracılığıyla elde edilen veriler bir sosyal temsil çalışması için iyi bir başlangıç noktasıdır (Lahlou ve Abric, 2011). Bu bölümde barış ve savaş temsil içeriklerinin serbest çağrışım yöntemiyle elde edildiği çalışmaların sonuçlarına yer verilmiştir (Bkz. Tablo 2). İncelenen çalışmalarda (Linden vd., 2011; Sarrica, 2007; Sarrica ve Wachelke, 2010) savaş temsilinin genel olarak somut, barış temsilinin ise soyut kutuplarda yer aldığı görülmektedir. Savaş temsili içeriğinde ölüm (\% 45.67), şiddet ( \%7.14), yıkım (\% 20.66), adaletsizlik (\% 6.66) ve yoksulluk ( \%5.75) gibi savaşın olumsuz sonuçları ve deneyimlerine yönelik tanımlamalar; nefret (\%10.35), korku ( \%7.53) ve acı ( \%6.09) gibi olumsuz duygular ve kan (\%8.16), silah (\%12.64), bomba (\%5.58) gibi canlı imgeler ve somut objeler yer almaktadır. Barış temsili içeriğinde ise mutluluk (\%20 .58), sevgi (\%20.44), huzur (\%15) gibi olumlu duyguların; insan hakları ile örtüşen özgürlük (\%13.90), yaşam (\%5.74) ve refah (\%4.61) elementlerinin; kişilerarası ilişkiler ve düzeni yansıtan uyum (\%13.14), birlik (\%8.26), arkadaşlık (\%8.66), yardımlaşma (\%6.03) elementlerinin ve bir tür barış sembolü olangüvercin (\%6.19) metaforunun yer aldığı görülmektedir. 
44 | Kübra Özkan Demir

Tablo 1. İncelenen Çalışmaların Genel Özellikleri

\begin{tabular}{|c|c|c|c|c|c|c|}
\hline & illk Yazar/YYl & Üllke & Örneklem & $\begin{array}{l}\text { Arașturma } \\
\text { Türü }\end{array}$ & ölẹüm Aracl & Analiz Yontemi \\
\hline 1 & Hakvoort, 1995 & Hollanda & $\begin{array}{l}\text { Iilkogrecim ve Lise } \\
\text { ögrencileri (8-16) }\end{array}$ & Nicel & $\begin{array}{l}\text { Aclk Uclu Gortșme } \\
\text { Formu }\end{array}$ & Tema Analizi \\
\hline 2 & Covell, 1994 & Kanada & $\begin{array}{l}\text { IVoogrecim ve Lise } \\
\text { ogrencileri (7-18) } \\
\end{array}$ & Nicel & $\begin{array}{l}\text { Molakar ve Açk Uelu } \\
\text { Soru Formsu }\end{array}$ & İęerik: Analizi \\
\hline 3 & Wagner, 1996 & \begin{tabular}{|l|} 
Ispanya, \\
Nikaragua \\
\end{tabular} & Yecișvinler (18-50) & Nicel & Cagnişım tesci & $\begin{array}{l}\text { Uyum ve KLimeleme } \\
\text { Analizleri }\end{array}$ \\
\hline 4 & Ort, 2000 & \begin{tabular}{|l|} 
Israil, Filiscin, \\
Avtupa OHseleri \\
\end{tabular} & $\begin{array}{l}\text { Orca Ögrecim } \\
\text { ogrencileri (15-16) }\end{array}$ & Nicel & Öz-bildirim Olçekleri & Iliş̧kisel Analiz \\
\hline 5 & Sartica, 2004 & Iralya & $\begin{array}{l}\text { Barns A Afcivisci Olan ve } \\
\text { Olmayan Yecishlinlex }\end{array}$ & Nicel & Cagnisum Tesci & Uyum Analizi \\
\hline 6 & Soura, 2006 & Brezilya & $\begin{array}{l}\begin{array}{l}\text { iukogrecim Octrencileri } \\
(7-12)\end{array} \\
\end{array}$ & Nicel & Aplk Uẹlu Sotu Formu & Tema Analizi \\
\hline 7 & Daniel, 2005 & Kanada, Fransa & Anacksulu Ögrencileri & Nicel & Odak Grup Gordşmeleri & Gomulu Teori \\
\hline 8 & Sarrica, 2007 & Iralya & Universive ögrencileri & Nicel & Cagnisum Tesci & Yapısal Analiz \\
\hline 9 & Paez, 2008 & \begin{tabular}{|l|} 
ABD, Avrupa \\
Asye, Okyanusya \\
\end{tabular} & Universire ögrencileri & Nicel & Cagnisim Testi & Iliş̧kisel Analiz \\
\hline 10 & Hanson-Easey, 2009 & Avuscuralya & Yecisplinler (18-70) & Nicel & Cagnosım testi & Yapisal Analiz \\
\hline 11 & Sarrica, 2010 & Iralya & Lise ögrencileri (14-19) & Nicel & Cagnișım Testi & Yapisal Analiz \\
\hline 12 & Linden, 2011 & ABD, Danimarka & Universice ötrencileri & Nicel & Cagnisam tesci & Kameleme Analizi \\
\hline 15 & Cabecinhas, 2011 & S Asrika thoesi & Universice Ögrencileti & Nicel & Cagnisum Tesci & Yapısal Analiz \\
\hline 14 & Leone, 2012 & Iralya & Universice ötrencileri & Nicel & Özbildirim Olçekleri & İlişkisel Analiz \\
\hline 15 & Gibson, 2012 & Binleşik: Kralluk & Televizyon Programlan & Nicel & - & Sbylem Analizi \\
\hline 16 & Zamperini, 2012 & Iralya & Haber ịererikleri & Nicel & - & Tema Analizi \\
\hline 17 & Montiel, 2012 & Filipinler & $\begin{array}{l}\text { Mostluman ve Hrisciyan } \\
\text { Gruplar, Haber } \\
\text { icerikleri } \\
\end{array}$ & Karma & Cagnişım Tesci & $\begin{array}{l}\text { Yap1sal Analiz, } \\
\text { Tema Analizi }\end{array}$ \\
\hline 18 & Montiel, 2015 & Filipinler & $\begin{array}{l}\text { Universice Ogrencileri, } \\
\text { Mostuman ve Hrisciyan } \\
\text { Liderler } \\
\end{array}$ & Karma & $\begin{array}{l}\text { Cagnisım Tesci } \\
\text { Odak Grup Gordsmeleri }\end{array}$ & $\begin{array}{l}\text { Yapisal Analiz, } \\
\text { Tema Analizi }\end{array}$ \\
\hline 19 & Bobowic, 2014 & $\begin{array}{l}6 \text { fankli karadan } \\
36 \text { tuke } \\
\end{array}$ & Universioe Ögrencileri & Nicel & Cagnisım Testi & İçerik Analizi \\
\hline 20 & Alcras, 2014 & Turkiye & Ortabgrecim ögrencileri & Nicel & Molakar & Tema analizi \\
\hline 21 & Noyanzina , 2015 & Rusya & \begin{tabular}{|l}
$\begin{array}{l}\text { Gencler ve Yerisklinler } \\
(15-75)\end{array}$ \\
\end{tabular} & Nicel & Cagnisim Tesci & Anlam Analizi \\
\hline 22 & Ryan, 2016 & ingilcere & Yeciskinler (18-87) & Karma & Cagnisum Tesci & İçerik Analizi \\
\hline 25 & Psaltis, 2016 & \begin{tabular}{|l|} 
Tubns-Turk-Rum \\
Kesimleri
\end{tabular} & Yexiskinler (18-) & Karma & Molakar & Tema Analizi \\
\hline 24 & Avraamidou, 2019 & \begin{tabular}{|l|} 
Fubris-Rum \\
Kesimi \\
\end{tabular} & $\begin{array}{c}\text { Fubrns-Rum Yerel } \\
\text { Gazereleri }\end{array}$ & Nicel & $\cdot$ & Tema Analizi \\
\hline 25 & Bayad, 2020 & Turkiye & Ortabgrecim ögrencileri & Karma & Apelk: Uelu Anker Formu & Ị̇erik: Analizi \\
\hline
\end{tabular}


Tablo 2. İncelenen Çalışmalarda Ortak Görülen Barış ve Savaş Temsili Elementleri*

\begin{tabular}{|l|l|l|l|}
\hline Savaş Temsili Elementleri & $\begin{array}{l}\text { Ort. Yüzde } \\
(\%)\end{array}$ & Barış Temsili Elementleri & $\begin{array}{l}\text { Ort. Yüz- } \\
\text { de(\%) }\end{array}$ \\
\hline Ölüm & $\% 45.67$ & Mutluluk & $\% 20.58$ \\
\hline Yıkım & $\% 20.66$ & Sevgi & $\% 20.44$ \\
\hline Silah & $\% 12.64$ & Huzur & $\% 15.00$ \\
\hline Nefret & $\% 10.35$ & Özgürlük & $\% 13.90$ \\
\hline Kan & $\% 8.16$ & Uyum & $\% 13.14$ \\
\hline Korku & $\% 7.53$ & Arkadaşlık & $\% 8.66$ \\
\hline Şiddet & $\% 7.14$ & Birlik & $\% 8.26$ \\
\hline Adaletsizlik & $\% 6.60$ & Güvercin & $\% 6.19$ \\
\hline Acı & $\% 6.09$ & Yardımlaşma & $\% 6.03$ \\
\hline Yoksulluk & $\% 5.75$ & Yaşam & $\% 5.74$ \\
\hline Bomba & $\% 5.58$ & Refah & $\% 4.61$ \\
\hline
\end{tabular}

\section{Cinsiyet Farklılıkları}

Barış ve savaş temsil içeriklerinin cinsiyete göre farklılaştığı görülmektedir. Genel olarak kadınlar savaş karşıtlığını içeren temsil içeriklerini daha sık kullanırken, erkekler ise gruplararası ve politik meselelere ilişkin tanımlamaları daha sık kullanmaktadır. Örneğin, Sarrica ve Wachelke (2010) erkeklerin politik aktörlere daha fazla atıfta bulunduğunu, kadınların ise sosyal adalet boyutlarına (yoksulluk, eşitlik gibi) daha çok vurgu yaptığını öne sürmektedir. Linden vd. (2011) çalışmasında da benzer bir şekilde kadınların erkeklere nazaran eşitlik, korku, yoksulluk gibi temaları daha sık kullandıkları görülmüştür. Aynı çalışmada cinsiyet ve savaşa/ barışa yönelik tutumlar arasındaki ilişkiler incelenmiş ve kadınların erkeklere kıyasla daha yüksek düzeyde savaş karşıtı oldukları bulunmuştur.

Çocuklarda da benzer bir eğilim görülmektedir. Brezilya'da ilköğretim çağındaki çocuklarla yürütülen çalışmada (Souza vd., 2006) barış temsili içeriğinde kız çocuklarının erkek çocuklara kıyasla olumlu duygulara ve insani tutumlara daha sık referans verdikleri, savaş temsili içeriğinde ise erkek çocukların kız çocuklarına kıyasla savaşın somut yönlerine (savaş aktiviteleri, silahlar, askerler) daha sık vurgu yaptıkları dikkati çekmektedir. Hakvoort ve Oppenheimer (1993)'ın 8-16 yaşları arasındaki çocuklarla yürüttükleri çalışmada da kız çocuklarının erkek çocuklarına nazaran barışı daha erken bir dönemde (8 yaş itibariyle) kavramaya başladıkları ortaya çıkmıştır. Bu çalışmada kız

\footnotetext{
*Serbest çağrışıma dayalı olarak barış ve savaş temsili içeriklerine ve sıklıklarına yer veren çalışmalarda (Linden vd, 2011; Sarrica, 2007; Sarrica ve Wachelke, 2010) yer alan ortak kelimelerin sıklıkları üzerinden ortalama sıklık yüzdeleri hesaplanmıştır.
} 
çocukları barış temsili içeriğinde erkek çocuklarına kıyasla olumlu duygulara daha fazla yer vermiş ve savaşı daha fazla olumsuz olarak tanımlamışlardır. Savaş temsili içeriğinde ise erkek çocukları savaşın somut yönlerine (silah, asker, ordu vb.), kız çocukları ise kavga ve münakaşa gibi kelimelere daha sık yer vermişlerdir. Sözü edilen çalışmalarla tutarlı olarak Türkiye'deki orta öğretim öğrencilerinin barış ile ilgili görüşlerinin alındığı çalışmada (Bayad vd., 2020) "barış için ne yapabilirsin?” sorusuna karşılık oluşturulan kişisel sorumluluk teması altında erkek çocukları somut çözümleri daha fazla sunarken, kız çocukları ise ilişkisel düzlemde çözümlere daha sık başvurmuşlardır.

Bağlam değiştikçe de cinsiyete göre temsil içeriklerinde farklılaşma olabilmektedir. Savaş temsilinin öncelikle verildiği koşulda kadınlar daha çok duygulara atıf yaparken, erkekler ise sıklıkla objelere ve pratikte karşılaşılan problemlere referans vermektedir. Barış temsilinin öncelikli verildiği koşulda ise erkekler savaşın sembolik yönlerine ve gruplararası ilişkilere odaklanırken, kadınlar ise daha çok yakın ilişkilere vurgu yapmaktadır (Sarrica ve Contarello, 2004). Daha geniş bir bağlamda Rusya'nın Sibirya Federal Bölgesi'ndeki dört farklı bölgesinde (Altay Krayı, Omsk Oblastı, Krasnoyarsk Krayı, Altay Cumhuriyeti) yürütülen çalışmada (Noyanzina vd., 2015) kadın ve erkeklerin aborjinleri ve bölgedeki diğer etnik grupları değerlendirme biçimlerinde farklılaşmalar olduğu görülmektedir. Kadınlar diğer uluslardan yakın ilişki içerisinde oldukları kişileri erkeklere kıyasla daha sık "saygıdeğer" olarak tanımlamışlardır. Erkekler ise aborjinleri “bizden”, "güçlü”, “doğal” ve "samimi” olarak değerlendirmişlerdir. Tam tersine kadınlar ise aborjinleri “öteki” olarak görürken, bu grubu yoksul ve ayrımcılığa uğrayan kesim olarak nitelendirmişlerdir.

\section{Yaş Farklılıkları}

Yapılan çalışmalarda barış ve savaşa ilişkin temsillerin yaş gruplarına göre de farklılaştığı görülmektedir. Yaş arttıkça barışın/savaşın çok yönlü doğasına atıfların arttığı, temsillerin içeriğinin çeşitlendiği/karmaşıklaştığı, kişilerarasından gruplar ya da uluslararası boyutlara ve somut kavramlardan soyut kavramlara geçişlerin olduğu görülmektedir. Hakvoort ve Oppenheimer (1993)'ın yaşları 8-16 (8,10,12,14,16 yaş grupları) arasında değişen Hollandalı öğrencilerle yürüttüğü çalışmada; analiz sonuçları tüm yaş grubundaki çocuklar savaşa dair detaylı bir bilgiye sahipken, kapsamlı bir barış fikrinin ise 10 yaş itibariyle oluştuğunu göstermektedir. Ayrıca 10 yaştan küçük çocukların barışı içinde bulundukları çevre ile özdeşleştirirken, on yaşından büyük öğrencilerin ise barışı evrensel bir hak olarak tanımlamaya başladıkları ve yaş grubuna dair bu farklılaşmanın anlamlı düzeyde olduğu tespit edilmiştir. 
Covell vd. (1994)'nin 7-18 yaşları arasında değişen Kanadalı öğrencilerle yürüttükleri çalışmada 11 yaşından sonra çocukların barışı ve savaşı soyut kavramlarla tanımlamaya başladıkları görülmüştür. Aynı çalışmada ki-kare testi sonuçları, on dört yaşındaki çocuklar barışı genellikle semboller ve kişisel düzeydeki temsiller (sakinlik, gülümseme vb.) ile açıllarken; 15-18 yaş aralığındaki çocuklar ise dünya barışı, şiddetsizlik gibi pozitif barışa tekabül eden tanımlamaların yanı sıra dünyanın çeşitli bölgelerindeki ülkelere ve tarihsel savaşlara da referanslar kullandıklarını göstermektedir.

Benzer yaş grubuyla Türkiye'de yürütülen çalışmada (Aktaş, 2014), ortaöğretim öğrencilerinin barış ile ilişkili olarak bireysel olumlu duygulara daha sık yer vermekle birlikte evrensel düzeydeki olumlu duygulara da referans verdikleri, barışı savaş ile ilişkilendirerek açıkladıkları ve barışı ayrımcılıkların olmadığı insan tutumlarıyla ve evrensel haklarla tanımladıkları görülmektedir. Çocukların temsilleri arasında doğaya ve dine ilişkin atıflar da yer almaktadır. Sosyal temsillerdeki yaşa bağlı değişimler cinsiyet grubuna göre de farklılaşmaktadır. Belçika'da 7 ve 13 yaşlarındaki iki farklı öğrenci grubundan elde edilen veriler (Souza vd., 2006), kız öğrencilerin barışla ilgili olumlu duygulara erkek çocuklarına kıyasla daha erken yaşlarda daha sık yer verdikleri görülmüştür. Aynı zamanda yaş̧̧a büyük çocuklar (13 yaş), 7 yaşındaki çocuklara kıyasla istatistiki olarak anlamlı bir şekilde barış temsili içinde insani tutumlara daha sık yer vermişlerdir. Savaş temsilinde ise savaşla ilgili aktiviteler, silah ve asker gibi somut öğeler erken yaştaki erkek çocukları tarafından sıklıkla kullanılırken, yaş ilerledikçe (13 yaş) erkek çocuklarında bu tür somut imgelerin kullanımı azalmıştır. Aksine 13 yaşındaki çocukların savaş temsili içeriğinde çıkar meselelerine ilişkin elementlere yer verme sıklıkları anlamlı bir şekilde artmıştır. Son zamanlarda Türkiye'de yapılan çalışmada ise (Bayad vd., 2020) 16 yaşından küçük çocukların barışı tanımlarken sembollere ve insanlar arası ilişkilere daha yüksek düzeyde atıfta bulunduğu, bu yaşın altındaki çocukların ise barışı tanımlarken yaşam kalitesi ve düzen ile ilişkili temsil elementlerine anlamlı olarak daha fazla yer vermişlerdir. Sarrica ve Wachelke (2010) çalışmasında ise 15-19 yaş grubundaki gençlerin sosyal adalet, şiddetsizlik, savaş deneyimleri ve güç ilişkilerini yansıtan kavramları kullanmaya başladıkları görülmüştür. Aynı zamanda toplumdaki “öteki”leri tanımlarken kullandıkları negatif tanımlamaları ise çatışma, gerginlik, tehdit, kültürün yozlaşması ile eşleştirerek duygularını temellendirmişlerdir.

İncelenen çalışmalarda barış ve savaş temsil içeriklerinin gelişimsel aç1dan yaşa bağlı değişimi çok sayıda araştırmanın konusu olmasına rağmen, yetişkin grupların temsil içeriklerinin yaş ile birlikte değişimi az sayıda çalışmada incelenmiştir. Bağlamsal farklılıkları incelemek amacıyla Sarrica ve 
Contarello (2004) tarafından yürütülen çalışmada, savaş kelimesinin önce verildiği koşulda gençlerin (18-25) savaşın somut yönlerine ve mantık ile örtüşmeyen doğasına ve kavramsal açıklamalara referans verdikleri; daha ileri yaş grubundakilerin (26-55) ise duyguları ön plana çıkarıp, savaşın yarattığı acizlik ve tükenmişlik duygularını içeren deneyimlere atıfta bulundukları görülmektedir. Yaşa bağlı bu farklılaşma araştırmacılar tarafından yetişkinlerin yaşanmışlıkları bağlamında öznel deneyimlerine daha çok yer verdikleri, gençlerin ise savaşı ussallaştırmakta ve dışsallaştırmakta oldukları şeklinde açıklanmıştır. Barış kelimesinin önce verildiği koşulda ise gençler barışın dışsal sembolik yönlerine, yetişkinler ise özgürlük, bağımsızlık gibi içsel değerlere atıf yapmışlardır. Diğer bir çalışmada ise (Noyanzina vd., 2015) üç yetişkin yaş grubunun (15-29, 30-49, 50-75) Rusya'daki farklı etnik gruplara karşı temsil içerikleri incelenmiş ve yaşlı neslin (50-75) etnik gruplara ilişkin olumlu tutumlarında toplumsal güvenlik, sosyal eşitsizlik, kültürel geleneklerin muhafazası ile ilişkili temsillerin daha geniş yer kapladığı görülmüştür. Ancak genç nesil (15-29) göçmenler, mülteciler ve diğer etnik azınlıklardan iğrendiklerini, onların yanında olmaktan tedirginlik ve güvensizlik hissettiklerini dile getirmişlerdir.

\section{Nitel Bulgular}

\section{Toplumsal Gruplar Arasındaki Söylemsel Farklılıklar}

Bir kültür içerisindeki sosyal grupların toplum içindeki konumunu belirlemesi, iç- grup/dış-grup aidiyetlerinin oluşması, grup bütünlüğünün sağlanması, bir hedefe ulaşmak için diğer grup üyeleriyle birlikte harekete geçmesi için paylaşılan söylemlerin, ideaların, sembollerin önemli bir rolü bulunmaktadır. Sarrica ve Contarello (2004) çalışması, İtalya'daki barış aktivistleri ile barışçıl eylem içerisinde bulunmayan kişilerin savaşa ve barışa ilişkin temsillerinin önemli noktalarda ayrıştığını gözler önüne sermektedir. Barışçıl eylemlerde bulunmayan kişiler savaşı yaşamı tehdit eden, karşısında hiçbir şeyin yapılamayacağı, güçsüzlük/çaresizlik/hayal kırıklığı yaratan trajik bir olay olarak değerlendirmişlerdir. Barış aktivistleri ise öte yandan barışçıl koşulların sağlanması için neler yapılabileceğine dair daha somut yaklaşım sergilemişlerdir. Örneğin, aktivist olmayanlar barışı “denge” olarak tanımlamaktadır ve sembollerle, yakın ilişkilerle ilgili tanımlamalara sıklıkla yer vermektedir. Aktivistler ise barışı "tartışma”, "müzakere” gibi dinamik tanımlamalarla ifade etmektedir. Bu çalışmanın önemli diğer sonucu ise barış kavramının sadece barış aktivistlerinde tutarlı, somut ve sınırları belirgin temsillerle karşılık bulmasıdır. Öyle ki, aktivistler barışı dinamik kelimelerle temsil ederken, 
aktivist olmayanlar ise barışı statik, bireysel ve dışsal sembollere bağlayan kelimelerle ifade etmektedir. Gruplararasındaki ayrışmanın diğer bir görünümü ise "çatışma" temsiline ilişkin olmuştur. Barış aktivistleri için çatışma doğal ve diyalektik iletişim için iyi bir araç olarak nitelendirilirken; aktivist olmayanlar için ise çatışma olumsuzlukları çağrıştırmış, duruma özgü ve kişilerarası olarak değerlendirilmiştir.

Farklı grupların sosyal temsilleri incelenerek gruplararası ilişkilerin dinamikleri anlaşılabilmektedir. Sosyal temsillerin anlamları derinlemesine incelendiği takdirde, tarihsel süreçte neler yaşandığına dair önemli ipuçları elde edilebilir. Montiel vd (2013) Müslümanlar ve Hristiyanlar'ın toprak sahipliğine yönelik kolektif olarak ürettikleri sosyal temsillerini incelemiştir. Filipinler'in güneybatı kesiminde Mindanao Özerk Bölgesi içinde yer alan Kuzey Cotabato'da yaşayan Müslüman ve Hristiyanlar arasında uzun zamandır politik çatışmalar bulunmaktadır. Hangi dini grubun "toprak sahibi”, hangisinin ise "toprakları gasp edenler” olduğu tartışması halen sıcaklığını korumaktadır. Hatta toprak hakkı üzerine süregiden bu tartışma Müslümanların öncülüğündeki Moro İslami Kurtuluş Cephesi (MILF) ve Hristiyanların öncülüğündeki Filipinler Cumhuriyeti Hükümeti arasında silahlı çatışmalara kadar ilerlemiştir. Bu tarihsel süreç ışığında iki grup ile yapılan çalışmada, “Cotabato'daki toprak sahipliğinin hikâyesini anlatacak olsaydınız hangi üç konudan bahsedersiniz?” sorusuna Hristiyanlar sıklıkla gruplararası çatışma, toprak meseleleri ve politik problemlerden bahsetmişlerdir. Düşük sıklıkta ise barış, güç savaşı ve Müslüman meseleleri kavramları yer almaktadır. Öte yandan Müslümanlar için bu tablonun yön değiştirdiği dikkati çekmektedir. Müslümanlar için en sık ve ilk olarak akla gelen temsil elementleri öz toprak meselesi, barış ve Müslüman meseleleri; daha az sıklıkta ifade edilenlerin ise gruplar arası çatışma, ayrışma/uyuşmazlık olmuştur. Politik çatışma ve şiddet ise ilk akla gelen temsillerden olmasına rağmen düşük sıklıkta söylenmiştir. Sosyal temsillerin bilişsel boyutuna tekabül eden bu temsillerin bile aynı konu üzerinde iki farklı grubun nasıl ayrıştığının bir resmini sunması açısından önemli görünmektedir. Aynı çalışmada Hristiyan ve Müslüman kanaat önderleri ile iki ayrı grupta odak grup çalışması yürütülmüştür (Montiel ve ark., 2013). Grup çalışmaları hem temsillerin içeriğini çeşitlendirmesi hem de grup etkileşimine açı olması nedeniyle bir konuya ilişkin daha derin bilgilere sahip olmanın önemli bir aracı olduğu düşünülmektedir. Bu grup tartışmasında, gruplar arasındaki ayrışmalardan biri Hristiyanların hukuki kaynaklara referans vererek (bürokrasiye dayalı) toprak sahibi olduklarını öne sürmeleri, Müslümanların ise nesilden nesile aktarılan hikâyelere dayanarak toprakların atalarından (royal family line) miras kaldığını iddia 
etmeleri olmuştur. Müslümanlar Hristiyanların topraklara zorla, aldatmaca, adil olmayan yollarla sahip olduklarını; Hristiyanlar ise toprakların Müslümanlar tarafından gönüllü bir şekilde satıldığını, sürecin tamamen adil ve dürüst ilerlediğini öne sürmüşlerdir.

Düşünsel ayrılıklar sadece farklı dinlere mensuplar arasında değil, aynı dine mensuplar arasında da görülebilmektedir. Mindano'daki çatışmaları sonlandırmak için 2008 yılında Filipin hükümeti ve Moro İslami Kurtuluş Cephesi arasında barış anlaşması imzalanmıştır (Montiel vd., 2012). Bu anlaşma ile birlikte Müslümanlar arasında da etnopolitik parçalanma olduğu görülmektedir. Müslüman bölge halkının bu anlaşmaya ilişkin görüşleri serbest çağrışım testi aracılığıyla analiz edilmiştir. Barış anlaşması denilince Müslümanların kontrolü ve hâkimiyeti; atalardan kalan topraklar, Mindanao'nun Filipinler'den bölünmesi; barış, düzen ve kalkınma; belirsizlik, güvensizlik, korku ve öfkeye ilişkin duygular; Müslüman hakları, özgürlük ve özyönetim gibi ana temalar altında toplanan temsil elementleri ortaya çıkmıştır. Her iki grubun da Müslümanlardan oluştuğu MoroUlusal Kurtuluş Cephesi (MNLF) ve Moro İslami Kurtuluş Cephesi (MILF) arasında temsil içeriğinin net olarak ayrıştığı dikkati çekmektedir. MILF barış anlaşmasının Mindanao'ya barış getireceğini ve bölgeyi kalkındıracağını ifade ederken; MNLF ise anlaşmanın bölgede silahlı çatışmaların ve şiddetin artmasına neden olacağını öne sürmektedir. Grupların Mindanao çatışmasındaki mekanizmaları; barış anlaşması sonrasında ortaya çıkan çatışmalardaki konumu; barış sürecinin geleceğe nasıl taşınacağına dair önerileri de birbirinden ayrışmaktadır.

Toplumsal barışın sağlanmasının koşullarından birinin farklı grupların sosyal temsillerini üst bir kolektif temsiller çatısı altında birleştirmek olduğu düşünülmektedir. Türkiye tarihini de yakından etkileyen politik olaylardan biri olan Kıbrıs sorununda her ne kadar Birleşmiş Milletler gibi uluslararası aktörlerin devreye girmesiyle müzakereler kolaylaşmış olsa da sorun halen tam anlamıyla çözümlenmiş değildir. Psaltis (2016) Kıbrıs tarihine ve sorununa ilişkin Kıbrıslı Rumlar ve Kıbrıslı Türkler tarafından paylaşılan sosyal temsilleri incelemiştir. Ne kadar bu iki kültürel grup ayrışık gibi görülse de yapılan görüşmelerin sonunda her iki grupta da üç farklı kimlik pozisyonunun ortak olduğu görülmektedir: Uzlaşma yanlısı, toplulukçu ve etnoulusal pozisyonlar. Uzlaşma yanlılarının diğer toplum üyelerine güvendikleri, geçmişteki yaralayıcı olaylar ile yüzleşip onları affedebildikleri, gruplararası temasa önem verdikleri ve gruplararası tehdit algılarının düşük olduğu görülmüştür. Her iki gruptaki sol ideolojiye sahip barış aktivistleri arasında bu tür temsiller sıklıkla paylaşılmaktadır ve toplumlararası barışı arzulamaktadırlar. Toplulukçu kimlik, etnoulusal sembollere bağlanma, tehdit algılama, güven 
ve temas azlığı şeklinde açıklanmaktadır. Etnoulusçuluk ise kendi etnik kökenini korurken diğer grupla temas sıklığının ve kalitesinin düşük, gruplararası güven ve affetmenin olmadığı durumları temsil etmektedir. Kendilerini muhafazakâr olarak tanımlayan kişilerin etnoulusçu olarak tanımladıkları görülmüştür. Yapılan görüşmelerde Türklerin etnoulusçu kimliklerinin, Rumların ise toplulukçu kimliklerinin daha belirgin olduğu ortaya çıkmıştır.

Kıbrıs sorununun halen çözülmemiş olmasının arkasında karşı tarafı suçlama eğiliminin devam ediyor olması ve bir tür kolektif temsil gibi işlev gören kolektif belleğin söylemlerle diri tutuluyor olmasından kaynaklanmaktadır (Psaltis, 2016). Bu çalışmada, Kıbrıslı Rumlar Türklerin yayılmacı politikası nedeniyle Kıbrıs sorununun halen çözülmediğini ifade ederken, Kıbrıslı Türkler ise Türkiye'yi yanlış politikası nedeniyle sorumlu tutmaktadır. Geçmişi değerlendirme biçimlerinde de farklılaşmalar görülmektedir. Rumlar geçmişte Türklerle olan ilişkisini olumlu değerlendirirken, Türkler ise daha olumsuz ve hoşnutsuzluk içeren temsilleri daha sık kullanmaktadırlar. Gruplararasında farklılaşan bir diğer temsil ise, Rumların Türklere kıyasla gruplararası teması daha fazla algılıyor olmasıdır. Türkler söylemleriyle Rumlara karşı daha mesafeli olduklarını, birlikte yaşamın mümkün olmadığını; aksine Rumlar ise Kıbrıs'ın birleşmesine ve barışın kurulmasına duydukları arzuyu dile getirmektedirler. Bu çalışmanın sonuçları kolektif olarak paylaşılan anlatıların gruplararası ilişkilerin iyileştirilmesinde kolaylaştırıcı rolünün yanı sıra, barışın kurulmasına da ket vuran özellikte olabileceğini göstermektedir. Kıbrıs-Rum kesimi barış müzakerelerinin başlangıcında ılımlı bir tavır sergilemelerine rağmen en son müzakerelerde geri çekilme kararı almıştır. Aveaamidou ve Psaltis (2019) Kıbrıs-Rum kesimin müzakerelerden geri çekilme kararı öncesinde (yaklaşık 4 aylık süreci kapsamaktadır) medyadaki barış müzakereleri temsillerini incelemişlerdir. Bu kapsamda iki yerel gazetede (Simerini ve Philelefheros) çıkan haberler ve yazıların içerikleri sosyal temsiller kuramı bağlamında ele alınmış ve Türkleştirme tehdidi, devletin dağılması, Helenizm'e yönelik tehditler ve güvenlik tehditleri temalarının medyada yaygınlıkla tartışıldığı görülmüştür. Araştırmacılar medya temsillerinin barış sürecinde dönüştürücü diyalog ortamının baltalanmasına zemin hazırladığını öne sürmektedirler.

\section{Tarihsel, Politik, Coğrafik ve Kültürel Bağlamların Ürünü Olarak Sosyal Temsiller}

Sosyal temsilleri, pozitivist yaklaşımlardan ayıran en ayırt edici özellik bağlama duyarlı olmalarıdır. Bağlamlar değiştikçe sosyal temsillerin içeriğinde de değişimler olabilmektedir. Sarrica ve Contarello (2004)'nun barış aktivisti 
olan ve olmayan grupla yürüttükleri çalışmada barış temsilinin önce verildiği koşulda cevapların daha araçsal ve derin anlamlarla ilişkilendirildiği görülmüştür. Savaş temsilinin önce verildiği koşulda ise aktivist olmayan grubun aktivist olanlara kıyasla barışı daha sembolik temsillerle ilişkilendirdiği dikkati çekmiştir. Peki, bu sonuçlar neden önemlidir? Eğer bir ülkede barış koşullarını sağlamak istiyorsak, daha yapıcı, umut vadeden, insanları olumsuz duygularından uzaklaştıran kavramları toplumun gündemine getirerek barışı yapmaya hazır oluşluk arttırılabilir. Bunu sağlamak için medyada, tartışma gruplarında, iktidarın ve halkın kullandığı söylemlerde barış çok yer almalıdır. Böylelikle temsilleri kalıcı kılmanın daha mümkün olacağı düşünülmektedir.

İletişim aracılığıyla temsillerin değişip kalıcı haline gelmesine örnek olarak Daniel vd (2006)'nin 5-6 yaşlarındaki çocuklarla uyguladıkları temel düzeyde şiddeti önleme programının sonuçları verilebilir. Şiddetin nedenleri, sonuçları, araçları ve şiddetten korunma yolları gibi temaların tartışıldığı grup çalışmasına dâhil olan çocukların cevapları gömülü teori yaklaşımıyla analiz edilmiştir. Grup tartışmaları öncesinde ve sonrasında elde edilen veriler niteliksel olarak karşılaştırıldığında oturumlarda tartışılan konular ile örtüşür şekilde yeni temsil içeriklerinin ortaya çıktığı görülmüştür. İtalyan yetişkin grubuyla 2004 ve 2005 yıllarında yapılan çalışmada da (Sarrica, 2007), barış, savaş ve çatışma temsillerinin yapısal kalıcılığı olduğu kadar değişim de gösterdiği görülmektedir. Bu çalışma İtalya'nın Kosova, Afganistan ve Irak savaşlarına müdahalesinin kamuoyunda yoğun bir şekilde tartış1lırken yürütülmüştür. Tartışmaların bir kutbu uluslararası sorunları çözmek amacıyla savaşa müdahale edilemeyeceğini öne sürerken, diğer kutbu ise hükümetin sadece insani yardımları ulaştırmak amacıyla bu sürecin içinde olduğunu savunmaktadır. Bu tartışmalar sürerken İtalyanların savaş, barış ve çatışma kavramlarından ne anladıkları üzerine veri toplanmıştır. 2004 ve 2005 yılları süresince, temsillerin çok az bir kısmında değişme olduğu görülmüştür. 2004 yılında savaş temsilinin özünü oluşturan kavramlar (ölüm, kan ve nefret) 2005 yılında da görülmektedir. Silah ve yıkım gibi temsiller 2004 yılında çevresel temsil iken, 2005 yılında merkezi öz de yer almıştır. Bu değişimde medyanın askeri operasyonların somut yönlerine ve sonuçlarına yaygınlıkla yer vermesinin etkisi bulunmaktadır. Bu tür tartışmaların diğer bir sonucu ise 2004 yılında acizlik duygularını yansıtan temsillerin (korku, ıstırap) yerini daha az korkutucu imgelere dönüşmüş olmasıdır. Askeri operasyonlar rasyonelleştirildikçe bireysel deneyimler de değişime uğramıştır. Öte yandan, barış temsilleri savaş temsili kadar tutarlı ve kalıcı bir yapı sergilememiştir. Barış temsili içeriğinde kişisel arzulara ilişkin idealler ve kişilerarası ilişkilere vurgu yapan elementler her iki yılda da merkezi özde yer 
almıştır. Metafor, imgeler ve soyut kavramlar ise her iki yılda da çevresel temsiller arasındadır. Özellikle 2005'te iş birliği, dayanışma ve tolerans gibi kavramların savaşın sıklıkla konuşulan bir mevzu olmasından kaynaklı olarak çevresel temsil içeriğine girmiştir. Öyle ki, savaş koşullarında barışın da konuşulmaya başlanması ve savaşın yıkıcı etkilerine karşı önlem alınması, o durumda verilebilecek muhtemel tepkiler arasında olduğu düşünülmektedir. Bu çalışmalar insan etkileşimleri esnasında sosyal temsillerin ortaya çıkışının kaçınılmaz olduğunu göstermektedir. Ancak temsiller her ne kadar gündemden yoğunlukla etkilense bile, kalıcı ve tutarlı bir yana da sahiptir. Zaten sosyal temsillerin böyle bir özelliği olmasa, insanların dünya üzerindeki ideolojik konumlarını belirlemeleri de bir hayli güç olacaktır.

İnsanlar içinde yaşadıkları kültürel, politik atmosferin yanı sıra geçmişten getirdikleri malzemeleri güncel söylemleri içerisinde koruyabilmektedirler. İnsanların kolektif tarihselliklerini "an"a taşıyan ve adeta kolektif bellek gibi işlev gören en iyi araçlardan birinin sosyal temsiller olduğu düşünülmektedir. Sosyal temsiller kuramı bağlamında, tarihsel ve politik bağlamlara odaklanan çok sayıda çalışma bulunmaktadır. Şüphesiz dünya savaşlarının ulusların kimlik inşasında önemli yeri vardır. Bobowic vd. (2014) 2. Dünya Savaşı'nda ulusların kazanan ya da kaybeden taraf olmasının savaş temsillerinin içeriğine ve savaşmaya ilişkin isteklerine yansıdığını ileri sürmektedir. Altı farklı kıtadan toplanan veriler sonucunda, 2. Dünya Savaşı'nda yenilgiye uğrayan ülkeler kolonilere ve kazanan ülkelere kıyasla savaşı facia, gereksiz ve adaletsiz olarak tanımlamışlardır. Kazanan ülkeler ise teknolojik ve bilimsel gelişmelere, ekonomik yeniden yapılanmaya, İnsan Hakları Bildirgesi'nin yayınlanmasına yol açtığı için olumlu algıladıklarını ifade etmişlerdir. Ancak koloniler hem yenilgiye uğrayan hem de kazanan ülkelere kıyasla 2. Dünya savaşını daha olumlu algılamaktadır. Çünkü bu savaş sayesinde modernizmin ve demokrasinin yolu açılmış ve sömürge kolonilerinden çekilip bağımsızlıklarını ilan etmişlerdir. 2. Dünya Savaşı'nı olumlu görenler ise savaşmaya daha istekli olduklarını ifade etmişlerdir (Bobowic vd., 2014; Paez vd., 2008). Hatta 21. Yüzyıl savaşları geçmiş dönemdeki savaşlara referans verilerek meşrulaştırılabilmektedir. Gibson (2012) Irak Savaşı'yla ilgili televizyonda yürütülen tartışma programlarının söylem içeriklerini incelediğinde ABD’nin Irak' a girmesinin meşruluğunu konuşan politik liderlerin 2. Dünya Savaşı'na referans verdiklerini ortaya çıkarmıştır. Politik liderler geçmişteki olaylar aracılığıyla bugünkü politikaları inşa edebilmektedirler. Sosyal temsiller yaklaşımına göre, bu çalışmada Irak Savaşı 2. Dünya Savaşı'na demirlenmiştir (anchoring). Çünkü Amerika için 2. Dünya Savaşı bir zaferdi ve Irak’a girdiğinde de başarıyla sonuçlanacağına dair geçmişten getirdiği 
temsiller bulunmaktadır. Ancak geçmiş tarihe ilişkin bu tür temsiller kültürel ve politik şiddet ortamını körüklemeye de devam etmektedir.

Öte yandan, geçmişteki önemli ve insanlık tarihini etkileyen tüm olaylar kolektif temsiller aracılığıyla her zaman bugüne erişememektedir. Cabecinhas vd (2011) dünya tarihinin hatırlanmasında dört farklı yanlılığın olduğunu öne sürmektedirler: Sonralık yanlılığı (yakın tarihteki olayların daha önemli algılanması), savaş ve politikaların merkezliliği (ulusun inşasında savaşlar, çatışmalar ve devrimlerin en önemli olaylar olarak hatırlanması), batımerkeziyetçilik yanlılığı (hatırlanan önemli olayların Avrupa ve Kuzey Amerika ile ilişkili olması), sosyomerkeziyetçi yanlılık (kendi uluslarıyla alakalı olan tarihsel olayların daha sık hatırlanması). Bu çalışmada sömürge altında olan ve insani gelişmişlik indeksi düşük, etnik çatışmalar ve sivil savaşların hüküm sürdüğü ülkeler arasında olan Sahra altı Afrika ülkelerinden veri toplanmıştır. Son 1000 yılda akla gelen en önemli tarihsel olayların, Avrupa ve Kuzey Amerika ile ilgili evrensel olaylar olduğu görülmüştür. Bölgeyi ilgilendiren olayların da sıklıkla hatırlanmasına rağmen, dünya savaşlarının hatırlanan olaylar arasında pek yer almadığı görülmektedir. Bu sonucun kolonileşmeden kurtuluşun olumlu algılanması ve bu olayların Afro-merkeziyetçi bakış açısından yorumlanmasından kaynaklandığı ileri sürülmektedir.

Ulusların tarihindeki savaş şiddetine dair detaylı ya da yüzeysel anlatıların nesilden nesile aktarılmakla kalmayıp uzlaşma süreci üzerinde de etkisi olduğunu ileri süren Leone ve Sarrica (2012) nesil geçişleri, sosyal amnezi ve uzlaşma süreci arasındaki ilişkilere odaklanmıştır. Etiyopya işgali sürecindeki savaş suçlarına dair vaka analizi aracılığıyla, İtalyanların çoğunun Etiyopya'yı işgali esnasındaki toplu katliamları görmezden gelmeleri açıklanmıştır. Etiyopya savaşı ile ilgili karşı tarafın maruz kaldığı şiddet detaylı anlatıldığında karşı tarafa ilişkin olumlu duyguların arttığı ve onarıcı davranışlara yöneldikleri görülmüştür. Diğer bir deyişle, anlatılarda iç-grup şiddet ve ölümlerden sorumlu tutulduğunda, taraflı olan gerçeklik sorgulanmaya başlamış ve onarıcı uzlaşmayı sağlamaya yönelik adımlar atılmıştır. Benzer bir çalışma Ryan ve Hewer (2016) tarafından 2. Dünya Savaşı esnasında İngilizlerin 1940-45 yılları arasında Almanya'yı bombalama olaylarını ne sıklıkta hatırladıklarını ortaya çıkarmak amacıyla yapılmıştır. Üç farklı yaş grubundan İngilizlerin olaya ilişkin kolektif temsilleri incelenmiştir. Katılımcıların \%43,2'si ebeveynlerinin ve büyük anne/babalarının 2. Dünya Savaşı ile ilgili konuştuklarını, geri kalanların ise hiçbir zaman konuşmadıklarını ifade etmişlerdir. İleri yaştaki katılımcıların çoğu ise bombalama, öldürme olaylarına ilişkin konuşmak istemediklerini, konuşanların ise bu olaylardan yüzeysel bir şekilde bahsettikleri görülmüştür. Barışın sağlanması için ön koşullardan 
birinin geçmişteki toplumsal olaylarla yüzleşme aşaması olduğu düşünüldüğünde, nesilden nesile aktarılan eksik ve yanlı anlatıların hakikati araştırma, hatalardan özür dilemeyi engelleyeceği ve dolayısıyla uzlaşının önünde engel oluşturacağı ileri sürülebilir. Hatta sadece barışı kurma da değil barış inşasında da sosyal temsillerin içeriğinin genişletilmesinin önemli olduğu düşünülmektedir. Hanson-Easey ve Moloney (2009) Afrika'dan Avustralya'ya göç eden mültecilere yönelik ulusal ve uluslararası insani yardım programlarının sıkça tartışıldığı 2001-2005 yılları arasında Avustralya vatandaşlarından veri toplamıştır. Medyada Afrikalı mültecilere yönelik tartışmaların ve görüntülerin sıklıkla yer alması sonucunda Sudan, Kongo, Liberya ve Kenya'dan gelen mültecilere ilişkin sosyal bilginin artması sosyal temsillerin içeriğini ve yapısını da etkilemiştir. Genel mülteci kategorisine kıyasla, Afrikalı mülteciler kategorisinde tutarlılık ve sabitlik olduğu görülmüştür. Mültecilerin menşei kökenine odaklanıldığında kıtlık, siyah, çocuk, üzgün, hastalık, savaş gibi temsillerin içeriğe girdiği dikkati çekmektedir.

Sosyal temsiller kuramı, gündemdeki politik olayların insanlar üzerindeki etkilerini söylemler aracılığıyla incelemeye de fırsat sunmaktadır. Zamperini vd (2012) Genova G8 zirvesi sonrasında polis ve aktivistler arasındaki çatışmaların eylemcilerin sosyal temsillerine nasıl yansıdığını incelemişlerdir. 24 Temmuz ve 2 Kasım 2001 tarihleri arasında üç sol kanat İtalya medyasındaki (Manifesto, Radio Popolare, Carta) aktivistlerin yazılarının yer aldığı 316 yazılı metin analiz edilmiştir. Medyada Genova, askerileşmiş bir şehir olarak temsil edilmektedir. Aktivistler kendilerini sırtından vurulmuş gibi hissetmekte, polisle olan çatışmalarını savaş olarak ifade etmektedirler. Ülkenin diktatör tarafından yönetildiğini ve aktivistlerin bu ülkede yeri olmadiğını sıklıkla dile getirmektedirler. Gruplararası ilişkilere ilişkin temsillerinde ise çatışmanın merkezinde kara blok ve polisin olduğuna yönelik temsillere yaygınlıkla yer verilmektedir. Aktivistler kendilerini şiddet kullanmayan, barışçıl kişiler olarak tanımlamakta, ancak kara bloğu ise itibarsız, şüpheli ve damgalanmış olarak resmetmektedir. Polis şiddet kullandığı için aktivistler kendilerini onlardan ayrıştırmakta ve polisin kamu güvenliğini ihlal ederek hem barışçıl gösterilerin hedefe ulaşmasını hem de aktivistlerin otoriteyle iletişimini engellediğini ifade etmektedirler. Ayrıca aktivistlerin çatışma ortamını demokratik ülkelerin özüne aykırı bulduklarını ve sürecin olağandışı/ mantıkdışı ilerlediğini dile getirdikleri dikkati çekmektedirler.

Ülke içindeki barış kültürünün yoksunluğu kültürlerarasında yapılan çalışmaların kolektif temsillerine de yansımaktadır. Linden ve ark (2011) politik kültürün savaş ve barışa ilişkin temsillere etkisini incelemek amacıyla $\mathrm{ABD}$ ve Danimarka'da çalışma yürütmüşlerdir. Danimarka'da militarizm ve 
gayrisafi yurtiçi hâsıladan silahlanmaya ayrılan pay diğer Avrupa ülkelerine kıyasla oldukça düşük seviyededir. Öte yandan, ABD’nin gerek 2. Dünya Savaşı'nda kazanan taraf olmanın gururunu yaşıyor olması gerekse de dünyanın şiddeti en çok kullanan ülke olarak bilinmesi nedeniyle barışçıl bir ülke olan Danimarka ile karşılaştırmışlardır. Danimarkalılar barışı “pozitif barış” ile ilişkilendirerek özgürlük, refah, demokrasi, yaşam, istikrar, ilerleme gibi kelimelerle temsil ederken; Amerikalılar ise daha çok kişisel duygulara (sakinlik, sevgi, huzur) ve metaforlara (güvercin, gökkuşağı vb.) yer vermişlerdir. Savaş temsilinde ise Amerikalılar daha çok aleni şiddete referans verirken; Danimarkalılar hem aleni hem de dolaylı şiddete ilişkin temsil elementleri kullanmışlardır. İspanyalı ve Nikaragualı yetişkinlerle yürütülen çalışmanın sonuçları ise (Wagner vd, 1996) henüz sıcak bir çatışma ortamından çıkmış olmanın barış ve savaş temsillerine nasıl yansıdığını göstermektedir. Sivil savaşın henüz bittiği Nikaragua'da hem savaş hem de barış temsili içeriği belirgin ve tutarlı bir yapıda iken; daha barışçıl bir iklime sahip olan İspanya'da ise sadece savaş temsilinin belirgin ve tutarlı yapıda olduğu görülmüştür. Nikaragualılar’ın barış temsilinin özünde "karşılıklı alıp vermek, dayanışma, saygı ve özgürlük” yer almaktadır. Savaş temsillerinin özünde ise İspanyalılar "korku, endişe" gibi duygulara yer verirken; Nikaragualılar savaş deneyimlerine (örn., sefalet) referans vermişlerdir. Çevresel temsillerde ise İspanyalılar savaşa ilişkin daha genel temsilleri kullanırken, Nikaragualılar ise kendi ülkelerinin savaş koşulları ile ilişkili temalara (örn. ekonomik abluka) yer vermişlerdir. Bu çalışmalarda birbiriyle çatışma halinde olmayan ülkelerin kıyaslandığı görülmektedir. Peki sıcak çatışmanın tarafı olan ülkelerde sosyal temsillerin görünümü nasıldır? Bu duruma Orr vd (2000)'nin çatışma altındaki İsrailli ve Filistinlilerin barış ve savaşa dair sosyal temsillerinin Avrupalı grupla karşılaştırdığı çalışma örnek olarak verilebilir. Bu çalışmanın sonuçları çatışan tarafların savaşı meşrulaştırmak adına bir tür kolektif savunma mekanizması olarak benzer sosyal temsillere referans verdiklerini göstermektedir. Hem İsrail hem de Filistinliler için ülke güvenliği Avrupalılara kıyasla daha büyük öneme sahiptir. Ek olarak Avrupalılardan farklı olarak İsrail ve Filistinliler kendi ülkelerini ve ulusal bağımsızlıklarını korumak adına savaşları daha meşru görmektedirler. Çatışan grupların savaşı meşru kılmak için tarihsel iyimserlikler sergiledikleri de görülmektedir. Ancak İsraillilerin tarihsel değerlendirmeleri daha iyimserken; Filistinlilerin ise daha karamsardır. Ancak ne kadar savaşlar haklı gerekçelere bağlanarak savunulsa bile savaşın yıkıcı etkilerine bilfiil maruz kalan Filistinli ve İsrailliler, Avrupalılara kıyasla, barış için bedel ödemeye daha isteksiz görünmektedirler. 


\section{Sonuç}

Geniş kitleleri etkileyen sosyopolitik olayları bireyin içsel özelliklerine ya da kişilerarası süreçlere indirgeyerek açıklama eğiliminde olan kuramların aksine; bu çalışmanın özünü oluşturan sosyal temsiller yaklaşımı, genel toplumsal inanışların gruplararası ilişkiler üzerindeki etkilerini tarihsel ve kültürel bağlamlar içinde inceleyerek üst düzeyde açılamalar getirme çabasındadır (Doise, 1986). Bu çalışmada da sosyal temsiller kuramı ışığında yürütülen barış, savaş ve çatışma ile ilişkili çalışmalar bağlamsal faktörler göz önünde bulundurularak incelenmiştir. Sosyal temsiller yaklaşımı temsillerin tartışmalı, çatışmalı ve etkileşimin olduğu ortamlarda daha rahat ortaya çıktığını öne sürmektedir (Moscovici, 1981). Bu nedenle insan iletişiminin doğal akışında ortaya çıkan temsillerin değişime açık ve dinamik yapıda olduğu düşünülür. Sosyal temsiller üzerine yapılan çalışmalar, barış ve savaşa ilişkin temsil içeriklerinin dönemsel olaylardan etkilenerek değiştiğini göstermektedir (örn., Sarrica, 2007; Daniel vd., 2006). Temsillerin bağlama duyarlı ve dinamik oluşunun yanı sıra boylamsal çalışmalar incelendiğinde zaman içinde barış ve savaş temsillerinin merkezi özünün kendini koruduğu, değişimin çevresel elementlerle sınırlı olduğu dikkati çekmektedir. Bu açıdan bakıldığında barış, savaş, çatışma temsillerinin bağlama duyarlı olduğu kadar değişime karşı kendini koruyan yapıya da sahip olduğu söylenebilir.

Öte yandan, bu çalışma kapsamında incelenen sosyal temsillere ilişkin boylamsal çalışmalardan, bir olguya ilişkin tartışma ortamı sona erdiğinde temsillerin halen kalıcı olup olmadığı bilgisine net olarak ulaşılamamaktadır. Çünkü bu çalışmalar politik tartışmaların ve olayların sıcaklığını halen koruduğu dönemlerde yürütülmüştür (bkz. Sarrica, 2007). Sosyal temsillerin gerçekliği inşa etmeye yarayan süreçlerinden biri demir atmadır. Bu süreç sayesinde yeni, yabancı, garip fikirlerin, nesnelerin ya da olayların tanıdık bir bağlam ya da kategori içerisinde yeniden düzenlenmesi sağlanır (Moscovici, 1984). Tarihsel, kültürel, politik bağlamların sosyal temsillerin içeriğine olan etkisinin incelendiği bölümde, geçmişteki önemli tarihsel, politik olayların halen gündemi etkiliyor olması uzun yıllar boyunca sosyal temsillerin kalıc1lığını koruyor olduğunun bir göstergesi sayılabilir. Ancak burada sözü edilen kalıcılık statik değildir; temsiller toplumsal bağlamlar ile dinamik bir şekilde etkileşime girerek yeniden inşa edilerek varlığını korumaktadır. Bu yönüyle sosyal temsiller kuramı, barış ve savaşa dair olguların açıklanmasında hem bugünün hem de geçmişin koşullarını sentezleyerek bir yön çizilmesine önemli katkı sunacaktır. 
Her ne kadar sosyal temsiller kültüre, bağlama özgü olarak anlaşılsa da yapılan çalışmaların sonuçları farklı kültürlerde/topluluklarda üretilen sosyal temsillerin bir ölçüde benzerlik taşıdığını göstermektedir. Barış çalışmalarında da barışın önüne ket vuran bağlama özgü risk faktörleri, toplumsal kırılmalar, hassasiyetler ya da kolektif hatıralar temsiller aracılığıyla çalışılarak kültürün iç-dinamikleri analiz edilebilir. Kültürlerarası çalışmalar aracılığıyla da farklı kültürlerdeki barışı anlamlandırma biçimleri incelenerek ortaklıklar üzerinden evrensel barış kültürü ortamının hazırlanmasina zemin hazırlanabilir.

\section{Kaynakça}

Abric, J. C. (2001). A Structural Approach to Social Representations. İçinde K. Deaux, ve G. Philogene (Eds.), Representations of the Social: Bridging Theoretical Traditions, (ss. 4247), Oxford: Blackwell Publishers.

Aktaş, Ö. (2014). Ortaöğretim Öğrencilerinin Savaş ve Barış Kavramına Yönelik Düşünceleri. Kalem Eğitim ve Sağlık Hizmetleri Vakfı, 65-124.

Bar-Tal, D. (1997). Formation and Change of Ethnic and National Stereotypes: An Integrative Model. International Journal of Intercultural Relations, 21, 491-523.

Bayad, A., Sakin, E., \& Cesur, S. (2020). Orta Öğretim Öğrencilerinde Barışın Sosyal Temsilleri. Türk Psikoloji Dergisi, 35, 13-29.

Blumberg, H. H. (2006). Trends in Peace Psychology. İçinde H.H. Blumberg, A.P.Hare ve A. Costin (Eds.), Peace Psychology: A Comprehensive Introduction, (ss. 3-15), UK: Cambridge University Press.

Bobowik, M., Páez, D., Liu, J. H., Licata, L., Klein, O., \& Basabe, N. (2014). Victorious Justifications and Criticism of Defeated: Involvement of Nations in World Wars, Social Development, Cultural Values, Social Representations Of War, and Willingness To Fight. International Journal of Intercultural Relations, 43, 60-73.

Cabecinhas, R., Liu, J. H., Licata, L., Klein, O., Mendes, J., Feijó, J., \& Niyubahwe, A. (2011). Hope in Africa? Social Representations of World History and The Future in Six African Countries. International Journal of Psychology, 46(5), 354-367.

Christie, D. J., Wagner, R.V., \& Winter, D.N. (2001). Introduction to Peace Psychology. İçinde D.J. Christie, R.V.Wagner., ve D.N.Winter (Eds.), Peace, Conflict and Violence: Peace Psychology for the 21th Century, (ss.1-15), USA: Prentice-Hall.

Cortright, D. (2008). Peace: A History of Movements and Ideas. New York: Cambridge University Press.

Covell, K., Rose-Krasnor, L., \& Fletcher, K. (1994). Age Differences in Understanding Peace, War, and Conflict Resolution. International Journal of Behavioral Development, 17(4), 717-737.

Daniel, M. F., Doudin, P. A., \& Pons, F. (2006). Children's Representations of Violence: Impacts of Cognitive Stimulation of A Philosophical Nature. Journal of Peace Education, 3(2), 209-234. 
Doise, W. (1986). Levels of Explanation in Social Psychology, Cambridge, UK: Cambridge University Press.

Elcheroth, G., Doise, W., \& Reicher, S. (2011). On the Knowledge of Politics and the Politics of Knowledge: How A Social Representations Approach Helps Us Rethink The Subject of Political Psychology. Political Psychology, 32(5), 729-758.

Galtung, J. (1969). Violence, Peace and Peace Research. Journal of Peace Research, 6, 167191.

Gibson, S. (2012). History in Action: The Construction of Historical Analogies in Televised Debates Concerning the Iraq War. Papers on Social Representations, 21, 1-35.

Hakvoort, I., \& Oppenheimer, L. (1993). Children and Adolescents' Conceptions of Peace, War and Strategies to Attain Peace: A Dutch Case Study. Journal of Peace Research, 30, 65-77.

Hanson-Easey, S., \& Moloney, G. (2009). Social Representations of Refugees: Place of Origin As A Delineating Resource. Journal of Community \& Applied Social Psychology, 19(6), 506- 514.

Höijer, B. (2011). Social Representation Theory, Nordicom Review, 32, 3-16

Jost, J. T., \& Ignatow, G. (2001). What We Do And Don't Know About The Functions Of Social Representations. Içinde K.Deaux, ve G. Philogene (Eds.), Representations of the Social: Bridging Theoretical Traditions, (ss. 190-198), Oxford: Blackwell Publishers.

Lahlou, S. V., \& Abric, J. (2011). What are the "elements" of a representation? Papers on Social Representations, 20, 1-10.

Leone, G., \& Sarrica, M. (2012). Challenging The Myth Of Italians As 'Good Fellows': Is Clarity About In-Group Crimes The Best Choice When Narrating A War To Its Perpetrators' Descendants?. Papers on Social Representations, 21(2), 1-28.

Linden, N., Bizumic, B., Stubager, R., \& Mellon, S. (2011). Social Representational Correlates Of Attitudes Toward Peace And War: A Cross-Cultural Analysis In The United States And Denmark. Peace and Conflict: Journal of Peace Psychology, 17(3), 217-242.

Liu, J.H., \& Sibley, C.G. (2009). Culture, Social Representations And Peace Making: A Symbolic Theory Of History And Identity. İçinde C.J. Montiel ve N.M. Noor(Eds.), Peace Psychology in Asia, (ss. 21-43), New York: Springer.

Macnair, R. M. (2015). Theories Underlying Research In Peace Psychology. İçinde D. Bretherton, ve S. F. Law (Eds.), Methodologies in Peace Psychology, (ss. 19-42), London: Springer Publications.

Montiel, C. J., Baquiano, M., \& Inzon, C. M. (2013). Conflicting Group Meanings Of Territorial Rights In Central Mindanao: Muslim-Christian Social Representations Of Land Entitlement. Journal of Pacific Rim Psychology, 7(01), 1-11.

Montiel, C. J., de Guzman, J. M., \& Macapagal, M. E. J. (2012). Fragmented Ethnopolitical Social Representations Of A Territorial Peace Agreement: The Mindanao Peace Talks. Journal of Pacific Rim Psychology, 6(02), 37-47.

Moscovici, S. (1981). On Social Representations. İçinde J. P. Forgas(Ed.), Social Cognition: Perspectives on Everyday Understanding, (ss.181-209), London: Academic Press.

Moscovici, S. (1984). The Phenomenon Of Social Representations. İçinde R. M. Farr, ve S. Moscovici (Eds.), Representations, (ss. 3-69), Cambridge, UK: Cambridge University Press. 
Moscovici, S. (1988). Notes Towards A Description Of Social Representations. European Journal of Social Psychology, 18, 211-250.

Moscovici, S.(2001). Social Representations: Explorations in Social Psychology. New York: New York University Press.

Noyanzina, O., Maximova, S., Goncharova, N., Omelchenko, D., \& Avdeeva, G. (2015).Interethnic Generalizations And Stereotypes In Mental Representations Of İmage Of 'The Other' In Social Representations Of Russian Population. Procedia Social and Behavioral Sciences, 185, 179-184.

Orr, E., Sagi, S., \& Bar-On, D. (2000). Social Representations In Use: Israeli And Palestinian High School Students' Collective Coping And Defense. Papers on Social Representations, 9, 1-20.

Paez, D., Liu, J. H., Techio, E., Slawuta, P., Zlobina, A., \& Cabecinhas, R. (2008). “Remembering" World War II And Willingness To Fight Sociocultural Factors In The Social Representation Of Historical Warfare Across 22 Societies, Journal of Cross-Cultural Psychology, 39(4), 373-380.

Philogene, G., \& Deaux, A. (2001). Introduction. İçinde K. Deaux, ve G. Philogene (Eds.), Representations of the Social: Bridging Theoretical Traditions, (ss. 3-7), Oxford: Blackwell Publications.

Psaltis, C. (2016). Collective Memory, Social Representations Of Intercommunal Relations, And Conflict Transformation In Divided Cyprus. Peace and Conflict: Journal of Peace Psychology, 22(1), 1-9.

Ryan, J. F., \& Hewer, C. J. (2016). What Did We Do To Germany During The Second World War? A British Perspective On The Allied Strategic Bombing Campaign 1940-45. Papers on Social Representations, 25(1), 1-28.

Sarrica, M. (2007). War And Peace As Social Representations: Cues Of Structural Stability. Peace and Conflict: Journal of Peace Psychology, 13(3), 251-272.

Sarrica, M., \& Contarello, A. (2004). Peace, War And Conflict: Social Representations Shared By Peace Activists And Non-Activists. Journal of Peace Research, 41(5), 549-568.

Sarrica, M., \& Wachelke, J. (2010). Peace And War As Social Representations: A Structural Exploration With Italian Adolescents. Universitas Psychologica, 9(2), 315-330.

Souza, L. K., Sperb, T. M., McCarthy, S., \& Biaggio, A. M. (2006). Brazilian Children's Conceptions Of Peace, War, And Violence. Peace and Conflict, 12(1), 49-63.

Wagner,W., Valencia, J., \& Elejabarrieta, F. (1996). Relevance, Discourse And The “Hot” Stable Core Of Social Representations. British Journal of Social Psychology, 35, 331-351.

Wessels, M. G., McKay, S.A., \& Roe, M.D. (2010). Pioneers in Peace Psychology: Reflections on the Series. Peace and Conflict, 16(4), 331-339.

Zamperini, A. O., Menegatto, M. U., Travaglino, G. A., \& Nulman, E. U. (2012). Social Representations Of Protest And Police After The Genoa G8 Summit: A Qualitative Analysis Of Activist Accounts Of Events. Pap Soc Represent, 21, 1-30. 